Volume 2 Nomor 2, September 2020, Halaman 118 - 138

\title{
Peer Edukasi Tentang Jajanan Kariogenik Pada Anak Usia Sekolah Di Desa Kandang Aceh Besar
}

\author{
Intan Liana $^{\text {1), Andriani }}{ }^{2)}$, Elfi Zahara ${ }^{3)}$ dan Anwar Arbi ${ }^{4)}$ \\ ${ }^{1,2,3)}$ Prodi Terapi Gigi Program Sarjana Terapan Jurusan Keperawatan Gigi \\ Poltekkes Kemenkes Aceh \\ ${ }^{4)}$ Fakultas Kesehatan Masyarakat Unmuha Banda Aceh \\ Email: intanliana1975@gmail.com ${ }^{1}$, andriani.muslimyes@ gmail.com ${ }^{2}$, \\ elfizahara98@gmail.com ${ }^{3}, \underline{\text { anwar68arbi@gmail.com }}$
}

\begin{abstract}
Abstrak
Sistem belajar yang efektif dalam mengajarkan teman sebaya adalah peer teaching (tutor sebaya), dengan lebih banyak melibatkan siswanya (student centered). Selama ini metode penyuluhan yang diberikan oleh guru dan atau instansi kesehatan lainnya menggunakan metode konvensional yaitu ceramah. Sementara itu, kasus karies gigi yang dialami pada umumnya dominan usia sekolah. Banyak kemungkinan karena usia anak sekolah sering jajan, baik disekolah maupun dirumah. Tujuan kegiatan pengabdian untuk meningkatkan pengetahuan dan upaya anak dalam memelihara kesehatan gigi dan mulut dari risiko jajanan kariogenik. Jumlah sasaran adalah 40 orang anak, yang dibagi dalam 4 kelompok besar, dan memilih 4 orang enumerator dari desa. Metode evaluasi dengan memberikan lembar kuesioner pre dan post test. Hasil kegiatan menunjukkan bahwa ada perbedaan nilai pengetahuan dan upaya memelihara kesehatan gigi dan mulut dari risiko jajanan kariogenik. Setelah dilakukan peer edukasi pada responden di Desa Kandang Aceh Besar. Maka dapat disimpulkan bahwa metode Peer edukasi sangat efektif untuk meningkatkan pengetahuan dan upaya memelihara kesehatan gigi dan mulut dari risiko jajanan kariogenik anak di Desa Kandang. Sehingga dapat direkomendasikan agar setiap instansi kesehatan dapat memberikan penyuluhan dengan menggunakan metode peer edukasi dan dengan melibatkan orang tua dan keluarga agar perubahan perilaku menjadi lebih baik.
\end{abstract}

Kata Kunci : Peer Edukasi, Kuesioner, Anak Usia Sekolah

\begin{abstract}
Abtract
The effective learning method used is peer teaching (peer tutoring), with studentcentered learning. So far, the method of counseling provided by teachers and / or other health institutions uses conventional methods, namely lectures. Meanwhile, cases of dental caries in school age children still rank first. There are many possibilities because school children often snack, both at school and at home. The aim of the service activities is to increase knowledge and actions to maintain dental and oral health from the risks of cariogenic snacks. The number of targets was 40 school-age children divided into 4 large groups, and selected 4 enumerators from the village. The evaluation method is to provide a pre and post test questionnaire. The results of the activity show that there are differences in the value of knowledge
\end{abstract}


and care for oral health from the risk of cariogenic snacks. After peer education was conducted on school-age children in Kandang Village, Aceh Besar. So it can be concluded that the Peer education method is very effective in increasing knowledge and taking care of dental and oral health from the risks of cariogenic snacks for school-age children in Kandang Village. So it can be recommended that every health agency can provide counseling by using peer education methods and by involving parents and families so that behavior change is better.

Key word : Peer Education, Questionnaire, School-aged Children

\section{A. Pendahuluan}

Keberhasilan suatu bangsa di masa depan ditentukan oleh kualitas anak-anak saat ini. Anak merupakan generasi penerus, dan sering disebut sebagai periode peralihan antara masa pra sekolah dengan masa remaja. Pada masa ini akan terjadi banyak perubahan, baik pada kondisi fisik, mental, sosial serta peningkatan kemampuan dan keterampilan motoriknya ( Afrilina, G., 2016).

Tumbuh kembang anak usia dini yang optimal sangat tergantung pada pemberian makanan dengan kualitas dan jumlah yang baik serta pemenuhan kebutuhan nutrisi atau gizi anak usia sekolah dasar sangat bergantung pada salah satu perilaku keluarga, terutama ibu dalam menyiapkan dan memberi makan anak. Perilaku dan kebiasaan keluarga merupakan hal terpenting untuk terciptanya sumber daya manusia yang berkualitas dan kompetitif. Salah satu perilaku penting yang harus terus dibudayakan adalah kebiasaan sarapan anak sekolah, karena sarapan terbukti mampu membuat anak lebih berkonsentrasi saat belajar di sekolah (Anggriana, D., 2014).

Kondisi kesehatan gigi serta mulut yang tidak sehat memerlukan penanganan segera karena memiliki keterkaitan dengan kesehatan tubuh anak. Kebiasaan sarapan pagi anak sangat penting untuk diperhatikan, karena selain untuk memenuhi kebutuhan nutrisi anak juga untuk mengurangi anak terpapar dengan jajanan tidak sehat yang dapat mengganggu susunan saraf pusat yang disebut juga dengan gangguan otak perut yang dapat menyebabkan perubahan perilaku seperti autism. Penyimpangan ini mengakibatkan gangguan pada banyak organ dan sistem tubuh anak. Masalah yang timbul sering disebut dengan food born diseases atau penyakit bawaan makanan, merupakan masalah kesehatan masyarakat yang utama 
di banyak negara seperti salah satunya akan menimbulkan masalah gangguan pencernaan (Messakh et al., 2019).

Di Indonesia, kebijakan pemerintah terkait penyediaan jajanan sekolah masih belum sepenuhnya menjalankan fungsi kontrol oleh pihak BPOM. Hal ini juga di dukung oleh perilaku penyedia yang kurang mempertimbangkan dampak negatif dari sajian yang di berikan pada anak sekolah. Kondisi tersebut menjadi ancaman bagi kesehatan yang diakibatkan oleh penyimpangan permilihan jenis makanan sangat potensial terjadi pada anak (Nurbiyati \& Wibowo, 2014).

Anak masih belum paham bagaimana memilih jajanan yang baik dan sehat untuk tubuhnya. Anak lebih senang pada jajan yang menarik dan enak, tanpa melihat manfaatnya. Aktivitas anak saat sekolah lebih banyak menyita waktu sehingga sering melupakan waktu makan dan cenderung lebih senang jajan. Kebiasaan jajan erat kaitannya dengan karakteristik personal (pengetahuan tentang jajanan, kecerdasan, persepsi, dan emosi), faktor jenis makanan, dan faktor lingkungan. Adanya kebiasaan jajan yang tidak baik perlu mendapat perhatian serius, agar dapat terhindar dari penyakit. Anak usia sekolah pada umur 7-11 tahun berada pada tahap perkembangan, dimana muncul pemikiran yang logis, sistematis, dan adanya kemampuan berfikir dari sisi orang lain, hal ini membuat anak sangat peka menerima perubahan dan pembaharuan (Nurbiyati \& Wibowo, 2014).

Pendidikan anak usia sekolah, selama ini selalu berupa teacher center, dimana guru sebagai focus pembelajaran, pola pembelajaran seperti ini juga lebih sering di gunakan, dalam proses pendidikan dimanapun. Sementara menurut Frankle, pendidikan sebaya memberikan banyak keuntungan terhadap anggotanya, seperti saling memotivasi dan saling menghargai antar sesama. Anak usia sekolah dalam bersosialisasi terhadap kelompok sebaya membuat aturan aturan yang harus dipatuhi oleh anggotanya dan mereka belajar untuk saling menghargai pendapat, memperlihatkan kemampuannya, memelihara reputasi anggotanya, saling membantu dalam menyelesaikan masalah (Lotfi Mainbolagh et al., 2012).

Hasil Riskesdas tahun 2018, menunjukkan bahwa penduduk Indonesia memiliki masalah kesehatan gigi hingga 57,4\%, namun hanya $10,2 \%$ yang mendapat perawatan oleh tenaga medis gigi. Dari seluruh penduduk, 88,8\% mengalami masalah karies gigi dan $74,1 \%$ menderita radang jaringan penyangga 
gigi, walau $94,7 \%$ penduduk setiap hari menyikat gigi, namun hanya $2,8 \%$ yang menyikat gigi pada waktu yang tepat dan benar yaitu pagi setelah sarapan dan malam sebelum tidur.

Berdasarkan penelitian yang dilakukan penulis di sekolah dasar Kecamatan Lueng Bata Banda Aceh, diperoleh hasil bahwa Ada perbedaan rerata pengetahuan anak diawal dan diakhir kegiatan peer edukasi dengan nilai $p=0,001$. Ada perbedaan rerata sikap anak diawal dan diakhir kegiatan peer edukasi tentang jajanan sehat $\mathrm{p} 0,001$. Ada perbedaan rerata tindakan anak diawal dan diakhir kegiatan peer edukasi tentang jajanan sehat p 0,001. (Liana, 2018)

Jajanan kariogenik, seperti coklat, permen atau gula-gula, serta makanan sejenis yang rasanya manis dan memiliki konsitensi melekat/lengket apabila di makan. Pada dasarnya semua jenis makanan kariogenik baik bagi kesehatan, hanya saja, cara mengkonsumsi, waktu mengkonsumsi dan cara membersihkan gigi setelah mengkonsumsi makanan tersebut yang dapat membahayakan kesehatan gigi anak (BPOM, 2013).

Masyarakat Aceh, pada anak usia sekolah, umur 7 - 12 tahun, juga memiliki kebiasaan yang sama dengan anak-anak lain pada umumnya, yaitu senang mengkonsumsi jajanan kariogenik, karena rasanya yang manis. Perilaku tersebut sangat mudah di lakukan anak, karena di desa Kandang, ada beberapa kios atau kedai kecil, yang banyak menjual jajanan untuk anak-anak. Tanpa bekal pengetahuan yang baik, tentunya anak desa Kandang berisiko untuk mengalami masalah kesehatan gigi dan mulut.

Selama ini, penyuluhan tentang kesehatan yang diberikan di desa, hanya pada kelompok sasaran ibu dengan balita, melalui program posyandu, dan sangat jarang, bahkan tidak pernah, anak-anak di Desa Kandang mendapat penyuluhan tentang jajanan kariogenik, mengingat lokasi sekolah yang berada di tengah desa, sehingga perangkat desa merasa pendidikan kesehatan sudah diperoleh anak-anak pada saat sekolah saja.

Oleh karena itu penulis tertarik untuk melakukan pengabdian masyarakat yang berjudul "Peer Edukasi Tentang Jajanan Kariogenik Pada Anak Usia Sekolah Di Desa Kandang Aceh Besar".

Adapun Tujuan kegiatan pengabdian masyarakat ini adalah untuk : 
1. Meningkatkan pengetahuan educator anak tentang jajanan kariogenik

2. Meningkatkan pengetahuan anak terkait upaya pemeliharaan kesehatan gigi dan mulut serta risiko jajanan kariogenik

3. Meningkatkan tindakan tentang bagaimana melakukan sikat gigi yang baik dan benar pada anak untuk menurunkan karies

Manfaat kegiatan ini dapat menambah pengetahuan dan wawasan bagi anak tentang pemeliharaan kesehatan gigi dan mulut serta risiko jajanan kariogenik pada anak sehingga diharapkan dapat meningkatkan status kesehatan gigi dan mulut anak usia sekolah di Desa Kandang Kecamatan Darul Imarah Kabupaten Aceh Besar.

Promosi kesehatan adalah pendekatan yang efektif, efisien dan berkesinambungan untuk mencapai kondisi sehat yang optimal. Pengertian ini telah dilengkapi lagi hingga dapat dikatakan bahwa promosi kesehatan merupakan suatu proses yang dapat meningkatkan kemampuan individu untuk dapat mengendalikan faktor-faktor yang mempengaruhi kesehatan, sehingga dapat meningkatkan derajat kesehatan mereka (Reitz \& Graham, 2018).

Menurut Piagam Ottawa, promosi kesehatan merupakan suatu proses untuk meningkatkan kemampuan individu untuk mengendalikan, dan mengelola kesehatan. Untuk mencapai derajat kesehatan fisik, mental dan sosial yang optimal dengan kemampuan untuk mengenali kebutuhan akan kesehatan dan mengubah lingkungan menjadi lebih kondusif. Dalam promosi kesehatan terdapat kegiatan pemberian informasi seperti penyuluhan, komunikasi, informasi dan edukasi (KIE), dan pendidikan kesehatan. Penyuluhan kesehatan merupakan bagian dalam kegiatan pendidikan kesehatan, yang dilakukan untuk menyampaikan informasi kesehatan. Seorang pendidik kesehatan tidak dapat menyamakan setiap orang untuk memiliki motivasi yang sama dalam melakukan perilaku kesehatan. Pendidikan kesehatan mempromosikan banyak pengalaman belajar untuk memfasilitasi kegiatan yang mendukung program kesehatan, dalam hal menambah pengetahuan baru, sikap dan perilaku baru yang dapat mengubah status kesehatan. Strategi pendidikan kesehatan ini dapat dilakukan mulai dari individu ke individu, kelompok dan masyarakat. Hubungan antara pembelajaran dan kesehatan telah diketahui sejak lama (Reitz \& Graham, 2018). 
Sistem belajar yang banyak dilakukan saat ini tentunya untuk menciptakan suasana belajar mengajar yang efektif, dan memberi ruang agar siswa dapat memiliki pemahaman yang baik, dan menyenangkan bagi guru dan para siswa. Lingkungan belajar yang kondusif, dan menyenangkan dapat meningkatkan motivasi guru untuk memberikan peranannya secara optimal, dalam menjalankan pembelajaran, dan pembimbing siswa. Hal ini juga berdampak positif bagi siswa Salah satu metode pembelajaran yang efektif digunakan adalah peer teaching. Mengajarkan teman sebaya bukanlah hal yang baru. Mengajarkan teman sebaya berarti siswa mengajar siswa lainnya atau yang berperan sebagai pengajar (tutor) adalah siswa. Anak yang saat itu berperan sebagai guru atau orang yang memiliki kemampuan lebih daripada siswa yang lain. Seorang tutor bisa juga adalah siswa yang diberikan tugas sebelumnya untuk mencari dan menemukan informasiinformasi sebagai bahan untuk belajar pada mata pelajaran tertentu, sehingga saat kegiatan belajar-mengajar berlangsung siswa tersebut dapat berperan sebagai tutor bagi teman-temannya di kelas. Jadi, tidak menutup kemungkinan semua siswa dapat menjadi pengajar asalkan siswa tersebut sudah memahami materi yang akan diberikan saat proses pembelajaran berlangsung. Mengajarkan teman sebaya juga seringkali digunakan untuk membantu, saat teman-temannya yang belum memahami pembelajaran yang diberikan. Mengajarkan teman sebaya biasanya lebih efektif bila dilakukan dengan jumlah siswa maksimal 20 orang. Sehingga materi yang disampaikan lebih mudah dipahami oleh teman-temannya. Hal utama dalam menggunakan metode pembelajaran teman sebaya ini adalah bagaiama melatih siswa agar lebih berani tampil di depan kelas. Serta dapat meringankan tugas guru, dalam penyampai informasi dan menghilangkan kesuntukan yang selalu dirasakan (De Vreede et al., 2014)

Makanan kariogenik adalah makanan yang mengandung fermentasi karbohidrat, sehingga berakibat pada menurunnya $\mathrm{pH}$ plak hingga $\pm 5,5$, hal ini dapat mempercepat terjadinya proses karies. Akibat konsumsi gula berlebih juga memberikan kontribusi untuk menyebabkan karies. Gula yang dikonsumsi akan dirubah menjadi polisakarida yang memungkinkan menjadi tempat perlekatan bakteri pada permukaan gigi, dan menjadi sumber cadangan energi pada proses 
ABDI WIRALODRA

JURNAL PENGABDIAN KEPADA MASYARAKAT
ISSN 2656-5501 (Print)

ISSN 2714-8041 (Online)

metabolisme karies selanjutnya serta bagi perkembangbiakan bakteri kariogenik (Ramayanti, 2013).

Makanan manis atau kariogenik bertahan 20-30 menit tidak berbahaya. Namun, apabila lebih dari 20 menit akan adanya perubahan sifat makanan menjadi asam, berdampak pada gigi akan mengalami kerusakan lebih cepat karena keadaan ini. Mengkonsumsi makanan kariogenik pH plak akan menurun dengan cepat setelahnya dan dapat menghancurkan email gigi. $\mathrm{pH}$ ini akan bertahan dalam mulut dalam waktu 30-60 menit sebelum akhirnya mencapai pH normal. Sebaiknya dalam kebiasaan mengemil makanan, hendaknya dibatasi 4 kali per sehari untuk total makanan kariogenik dan 3 kali per seminggu, sehingga perubahan $\mathrm{pH}$ dalam mulut dapat menetralisir asam yang ada dalam mulut (Ramadhan, 2010).

Tingkat kariogenitas makanan sangat tergantung dari : (a) Bentuk fisik, yaitu unsur karbohidrat dalam bentuk tepung atau cairan bersifat lengket serta mudah hancur saat di dalam mulut, seperti kue-kue, roti, es krim, susu, permen dan lainlain. (b). Jenis, unsur karbohidrat seperti polisakarida, disakarida, monosakarida dan sukrosa yang memiliki kemampuan lebih cepat terhadap pertumbuhan mikroorganisme asidogenik dibanding karbohidrat lain. (c). Frekuensi konsumsi, yaitu keseringan seseorang dalam ngemil makanan manis dan lengket akan mengakibatkan saliva dalam rongga mulut tetap dalam suasana asam akibatnya gigi akan semakin rentan terhadap karies (BPOM, 2013)

Makanan sangat berpengaruh terhadap gigi dan mulut, yaitu sebagai makanan yang menghasilkan energy, misalnya: karbohidrat, protein, lemak, vitamin serta mineral-mineral. Unsur-unsur tersebut diatas berpengaruh pada masa pra-erupsi serta pasca erupsi gigi geligi. Makanan juga memiliki fungsi mekanis yaitu bersifat membersihkan seperti : apel, jambu air, bengkoang dan lain sebagainya. Sebaliknya makanan-makanan yang lunak dan 15 melekat pada gigi dapat merusak gigi seperti: bonbon, cokelat, biskuit dan lain sebagainya (Fatimatuzzahro et al., 2016).

Makanan kariogenik terdiri dari berbagai macam jenis, diantaranya sebagai berikut : (1) Jenis cairan: minuman ringan, minuman buah, gula dalam minuman, es krim; (2) Jenis makanan padat dan lengket seperti: biskuit, permen kunyah, coklat, caramel, bauah kering, selay, jelly, marsmallow; (3) Jenis makanan lambat terlarut seperti: permen keras, obat tetes pereda batuk. Makanan jajanan adalah jenis 
makanan yang dimakan sepanjang hari, sebagai hiburan, tidak terbatas pada waktu tertentu, tempat dan jumlah yang dikonsumsi. Makanan jajanan sehat apabila terjamin kebersihannya, terbebas dari zat kimia berbahaya. Sementara itu, pada jajanan anak sekolah banyak ditemukan produk makanan yang tidak memenuhi persyaratan mutu dan keamanan yang menyebabkan banyaknya kasus keracunan makanan, disamping masih rendahnya pengetahuan dan tanggung jawab penyedia tentang mutu dan keamanan pangan (Messakh et al., 2019).

Anak usia sekolah membutuhkan keseimbangan diet nutrisi yang baik, seperti kebutuhan kalori, protein, mineral, lemak perhari untuk pertumbuhanya. Anak usia sekolah membutuhkan sekitar 2400 kalori perhari untuk kebutuhan pertumbuhan yang dikonsumsi selama 3 kali makan nasi, dan 1 atau 2 kali makan ringan. Kecenderungan anak untuk mencoba makanan baru, dan biasanya anak akan menunjukkan reaksi tidak suka pada jenis makanan seperti sayur, buah dan lainnya. Anak lebih menyukai jajanan disekolah sehingga dibutuhkan pengawasan yang baik dari anggota keluarga (Fatimatuzzahro et al., 2016).

Desa Kandang merupakan salah satu desa di wilayah Aceh Besar, dan berada di wilayah kerja Puskesmas Darul Imarah Kabupaten Aceh Besar. Kegiatan UKGS dan penyuluhan kesehatan sangat jarang dilakukan, karena terbatasnya petugas kesehatan gigi dan mulut dan luasnya wilayah daerah yang menjadi tanggung jawab puskesmas. Hal ini sangat memungkinkan rendahnya pengetahuan anak usia sekolah terkait jajanan sehat dan jajanan kariogenik. Kegiatan penyuluhan yang dilakukan hanya menggunakan metode ceramah, dan jumlah peserta sangat besar, sebab selalu dilaksanakan bertepatan dengan kegiatan perayaan besar di desa, seperti saat pengajian desa, saat maulid desa, dan lain-lain. Sehingga banyak audien yang tidak focus. Oleh karena itu kegiatan penyuluhan dengan metode peer edukasi, dengan melibatkan teman sebaya, sangat memungkinkan dapat memberikan informasi yang maksimal terkait makanan jajanan sehat, pemeliharaan kesehatan gigi dan risiko jajanan kariogenik.

\section{B. Metode}

Kerangka pemecahan masalah menggunakan teori perubahan perilaku menurut L. Green, yaitu factor-faktor mempengaruhi proses perubahan perilaku antara lain 


\section{ABDI WIRALODRA}

JURNAL PENGABDIAN KEPADA MASYARAKAT
ISSN 2656-5501 (Print)

ISSN 2714-8041 (Online)

predisposing factor yaitu pengetahuan sebagai factor predisposing dan factor tindakan. Dengan melibatkan semua factor tersebut, diharapkan dapat memberikan perubahan pengetahuan dan tindakan anak usia sekolah terhadap jajanan kariogenik, upaya pemeliharaan kesehatan gigi dan mulut. Adapun kerangka tersebut, seperti yang tergambar pada bagan dibawah ini :

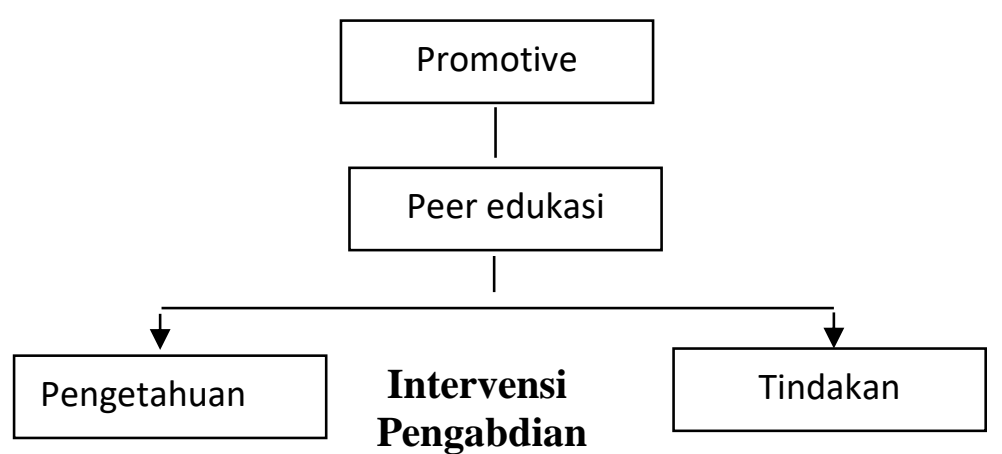

\section{Realisasi Pemecahan Masalah}

1. Terlaksananya kegiatan peer edukasi dan kelompok belajar pada anak usia sekolah di Desa Kandang Aceh Besar

2. Terlaksananya tindakan pemeliharaan kesehatan gigi dan mulut oleh anak usia sekolah.

Sasaran kegiatan pengabdian masyarakat ini adalah 40 anak, yang berusia antara 8 -12 tahun di Desa Kandang Kecamatan Darul Imarah Kabupaten Aceh Besar.

Metode yang digunakan dalam kegiatan ini adalah : ceramah dan demonstrasi oleh educator.

Adapun Langkah-langkah pelaksanaan kegiatan Pengabdian Masyarakat, adalah sebagai berikut :

1. Tahap persiapan

Kegiatan awal pengabdian masyarakat adalah mempersiapkan kebutuhan alat dan bahan yang akan digunakan, mengurus izin kepada kepala desa Kandang.

2. Tahap Pelaksanaan

Pelaksanaan Pendidikan kesehatan gigi dengan metode peer edukasi tentang jajanan kariogenik yang dalam upaya pencegahan karies gigi pada anak usia 
sekolah. Pelaksanaan kegiatan pengabdian masyarakat adalah sebagai berikut :

a. Anak yang berperan sebagai sebagai educator, sejumlah 4 orang anak, dipilih dengan syarat anak yang dianggap cakap oleh kader desa dan ustaz dan ustazah yang mengajarkan mengaji di meunasah desa. Educator yang terpilih diberikan pre sebelum diberikan atau diajarkan tentang materi, diberikan modul dan media saat diberikan penyuluhan kepada anak-anak yang lain. Educator juga diajarkan bagaimana melakukan sikat gigi dengan menggunakan phantom gigi. Educator di ajarkan materi jajanan kariogenik dan tehnik menyikat gigi selama lebih kurang 20 menit, satu hari sebelum kegiatan peer edukasi berlangsung. Setelah pemberian materi peer edukasi kepada educator, maka dilakukan post test.

b. Anak-anak dikumpulkan di sekolah karena balai desa atau meunasah sedang dalam berbaikan, kebetulan letak sekolah bersebelahan dengan menasah desa. Berhubung kondisi masih dalam suasana covid, maka anak-anak dibentuk dalam 4 kelompok besar, masing-masing beranggotakan 10 orang anak. Kelompok diatur kehadirannya di jam yang berbeda. Dengan mematuhi protocol kesehatan, yaitu mencuci tangan dengan hand sanitizer, menggunakan masker, face shield dan menjaga jarak.

c. Anak-anak yang hadir sesuai jamnya diberikan pre test melalui kuesioner yang dibagikan.

d. Educator yang telah siap untuk mengajarkan temannya yang lain yang berjumlah 10 orang dipersilahkan, selama lebih kurang 15 menit, tentunya dengan bimbingan tim kegiatan pengabdian masyarakat, sesuai dengan kelompoknya masing-masing.

e. Pada kegiatan evaluasi akhir, tim pelaksana mengumpulkan kembali anakanak dan memberikan post test.

Pengabdian masyarakat ini dilakukan oleh Dosen Poltekkes Kemenkes Aceh khususnya dosen Keperawatan Gigi dengan mengikutsertakan anak usia sekolah dan kader didesa. Kegiatan pengabdian masyarakat ini dapat memberikan manfaat bagi dosen di Jurusan Keperawatan Gigi, terkait kesehatan gigi dan mulut anak khususnya mengenai pencegahan karies gigi melalui peer edukasi tentang jajanan kariogenik. Dengan adanya pengabdian ini murid dapat memahami tentang jajanan 


\section{ABDI WIRALODRA}

JURNAL PENGABDIAN KEPADA MASYARAKAT
ISSN 2656-5501 (Print)

ISSN 2714-8041 (Online)

kariogenik dan mempu mempraktekkan cara menyikat gigi yang benar dirumah. Hal ini tentunya dapat meningkatkan kemampuan dosen dalam melakukan salah satu tugas pokok dosen dalam Tri Darma Perguruan Tinggi yaitu melakukan pengabdian masyarakat, dengan berkontribusi untuk membantu masyarakat dan memfasilitasi masyarakat terutama kelompok anak usia sekolah dalam meningkatkan kesehatan gigi dan mulut.

Kegiatan pengabdian masyarakat ini akan dilaksanakan dalam waktu 3 minggu (rencana intervensi) dan setiap kegiatan akan dilakukan evaluasi. Adapun tahapan dalam evaluasi melalui penilaian pre dan post test, diawal dan diakhir kegiatan.

Adapun indicator keberhasilan yang di buat adalah :

1. Educator dapat menjawab pertanyaan terkait materi jajanan kariogenik, dan adanya peningkatan nilai dari pre test ke post test.

2. Responden atau anak usia sekolah dapat menjawab pertanyaan terkait materi jajanan kariogenik, dan adanya peningkatan nilai dari pre test ke post test.

3. Responden atau anak usia sekolah dapat menjawab pertanyaan terkait perilaku atau tindakan cara pemeliharaan kebersihan gigi dan mulut, dan adanya peningkatan nilai dari pre test ke post test.

\section{Hasil dan Pembahasan}

Kegiatan pengabdian masyarakat yang berlangsung dari 16 September 2020 s.d 26 Oktober 2020, menghasilkan data yaitu sampel yang berjumlah 40 orang, terdapat 25 orang $(62 \%)$ berjenis kelamin perempuan dan 15 orang $(37,5 \%)$ berjenis kelamin laki-laki.

Kegiatan pengabdian masyarakat berupa mengajarkan siswa usia sekolah sebanyak 4 (empat) orang untuk menjadi educator, maka sebelum diberikan informasi dan pengetahuan terkait materi pengabdian kepada educator, terlebih dahulu dilakukan pre test, setelah informasi diberikan, dilanjutkan dengan postest, adapun hasil pre dan postest tersebut adalah sebagai berikut : 
Tabel 1. Distribusi Frekuensi Pengetahuan Hasil Pre Test dan Post Test Educator di Desa Kandang Tahun 2020

\begin{tabular}{ccccccccc}
\hline \multirow{2}{*}{ Hasil } & \multicolumn{4}{c}{ Pengetahuan } & \multicolumn{3}{c}{ Total } \\
\cline { 2 - 8 } Kegiatan & \multicolumn{2}{c}{ Rendah } & \multicolumn{2}{c}{ Sedang } & \multicolumn{2}{c}{ Tinggi } & \multirow{2}{*}{ F } & \multirow{2}{*}{$\%$} \\
\cline { 2 - 8 } & F & \% & F & \% & F & \% & & \\
\hline Pre Test & 2 & 50 & 2 & 50 & 0 & 0 & 4 & 100 \\
\hline Post Test & 0 & 0 & 1 & 25 & 3 & 75 & 4 & 100 \\
\hline
\end{tabular}

Berdasarkan tabel 1 menunjukkan bahwa adanya peningkatan pengetahuan educator setelah mendapat materi dan modul dari tim pengabdian masyarakat.

Tabel 2. Distribusi Frekuensi Tindakan Hasil Pre Test dan Post Test Educator di Desa Kandang Tahun 2020

\begin{tabular}{cccccccc}
\hline \multirow{2}{*}{$\begin{array}{c}\text { Hasil } \\
\text { Kegiatan }\end{array}$} & \multicolumn{3}{c}{ Kurang baik } & \multicolumn{2}{c}{ Baik } & \multirow{2}{*}{ Total } \\
\cline { 2 - 6 } & F & \% & F & \% & & \multirow{2}{*}{ F } \\
\hline Pre Test & 3 & 75 & 1 & 25 & 4 & 100 \\
\hline Post Test & 0 & 0 & 4 & 100 & 4 & 100 \\
\hline
\end{tabular}

Berdasarkan tabel 2 menunjukkan bahwa adanya peningkatan tindakan educator setelah mendapat materi dan modul dari tim pengabdian masyarakat.

Tabel 3. Distribusi Frekuensi Pengetahuan Hasil Pre Test dan Post Test Responden di Desa Kandang Tahun 2020

\begin{tabular}{ccccccccc}
\hline \multirow{2}{*}{$\begin{array}{c}\text { Hasil } \\
\text { Kegiatan }\end{array}$} & \multicolumn{9}{c}{ Pengetahuan } & \multicolumn{3}{c}{ Total } \\
\cline { 2 - 8 } & $\mathbf{F}$ & $\mathbf{\%}$ & $\mathbf{F}$ & $\mathbf{\%}$ & $\mathbf{F}$ & $\mathbf{\%}$ & \multirow{2}{*}{ F } & \multirow{2}{*}{$\%$} \\
\hline Pre Test & 18 & 45 & 12 & 30 & 10 & 25 & 40 & 100 \\
\hline Post Test & 9 & 22,5 & 13 & 32,5 & 18 & 40 & 40 & 100 \\
\hline P & \multicolumn{9}{c}{$0,001^{*}$} \\
\hline
\end{tabular}

Berdasarkan tabel 3 menunjukkan bahwa adanya perbedaan rata-rata pengetahuan sebelum dan sesudah diberikan penyuluhan oleh educator, dengan metode peer edukasi. 
Tabel 4. Distribusi Frekuensi Tindakan Pemeliharaan Kesehatan Gigi dan

Mulut Hasil Pre Test dan Post Test Responden di Desa Kandang Tahun 2020

\begin{tabular}{ccccccc}
\hline \multirow{2}{*}{$\begin{array}{c}\text { Hasil } \\
\text { Kegiatan }\end{array}$} & \multicolumn{3}{c}{ Turang baik } & \multicolumn{2}{c}{ Baik } & \multirow{2}{*}{ Total } \\
\cline { 2 - 6 } & F & \% & F & \% & & \multirow{2}{*}{ F } \\
\hline Pre Test & 28 & 45 & 12 & 30 & 40 & 100 \\
\hline Post Test & 9 & 22,5 & 31 & 77,5 & 40 & 100 \\
\hline P & \multicolumn{3}{c}{$0,001^{*}$} \\
\hline
\end{tabular}

Berdasarkan tabel 4 menunjukkan bahwa adanya perbedaan rata-rata tindakan sebelum dan sesudah diberikan penyuluhan oleh educator, dengan metode peer edukasi.

Berdasarkan kegiatan pengabdian masyarakat yang dilakukan pada tanggal 16 September 2020 s/d 26 Oktober 2020 di Desa Kandang Kecamatan Darul Imarah Kabupaten Aceh Besar. Tim educator yang telah dilatih, terdapat peningkatan pengetahuan dan tindakan, educator dibimbing bagaimana menjadi educator yang baik, sebelumnya educator telah di berikan modul, sebagai bekal pengetahuan sebelum dilakukan bimbingan oleh tim pengabdian masyarakat.

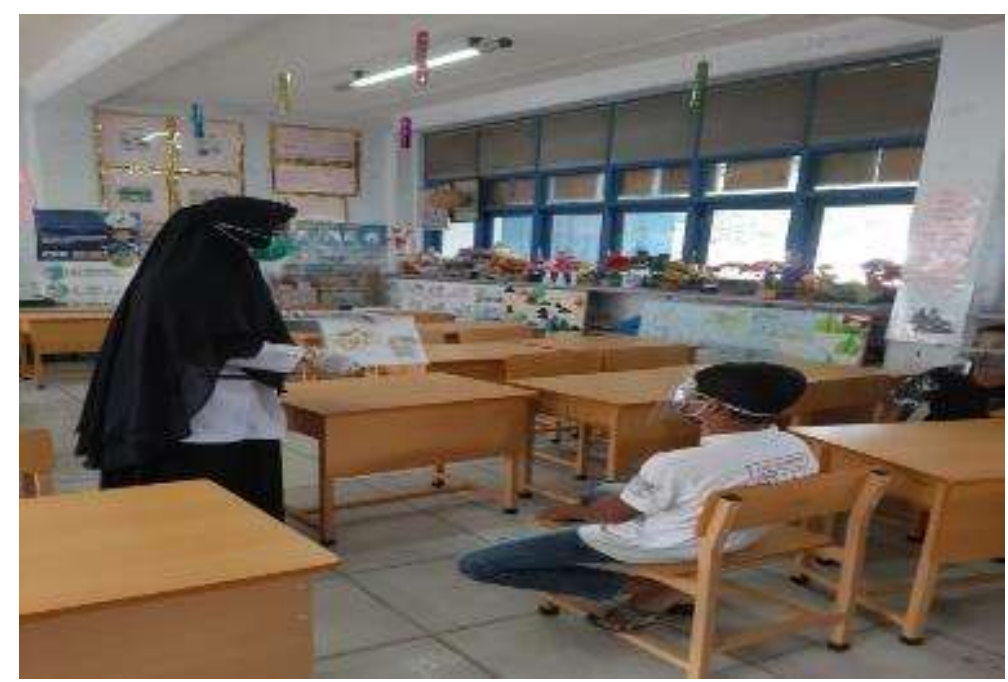

Gambar 1. Tim Pengabdian Sedang mengajarkan salah satu educator terkait materi tentang pemeliharaan kesehatan gigi dan mulut

Pada gambar 1. Terlihat tim pengabdian masyarakat sedang memberikan informasi tentang pemeliharaan kesehatan gigi dan mulut, dengan menggunakan media flip 
chart, media ini juga dapat digunakan oleh educator nantinya, saat memberikan penyuluhan kesehatan gigi dan mulut pada teman sebanyanya. Tentunya, tim pengabdian tetap mendampingi educator saat mengajarkan teman sebanyanya.

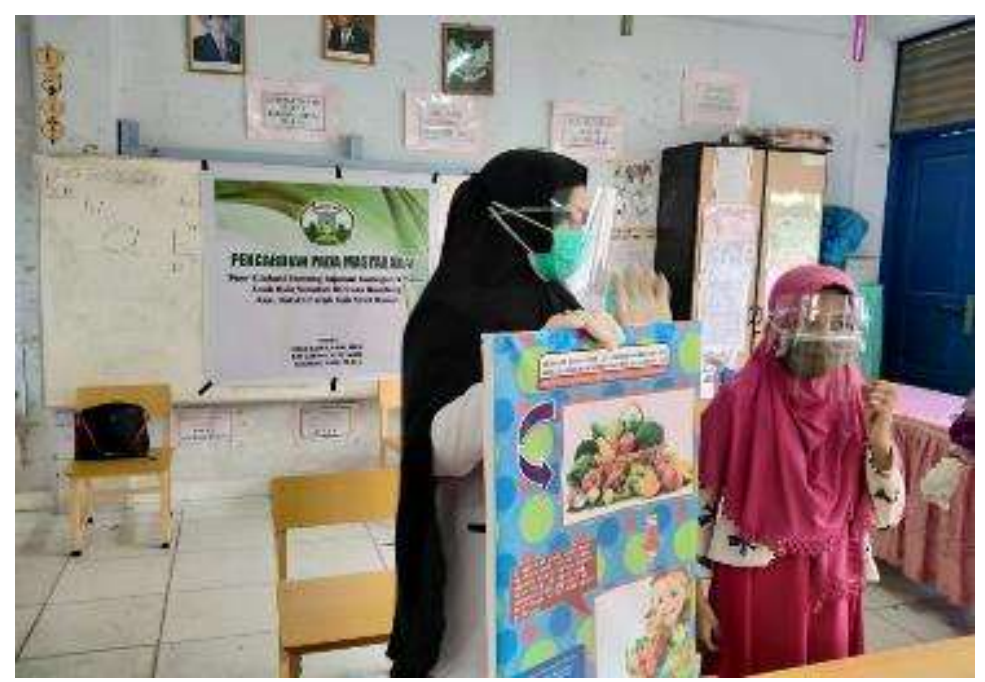

Gambar 2. Tim Pengabdian Sedang mendampingi salah satu educator terkait materi tentang jajanan kariogenik dan jajanan sehat untuk gigi dan mulut Pada gambar 2. Educator sedang memberikan penyuluhan kepada teman sebaya nya dengan menggunakan media poster. Educator sangat antusias dan senang bisa mengajarkan temannya yang lain, terlihat dari cara penyampaian dengan suara yang jelas, dan informasi yang diberikan juga benar.

Sebelum dilakukan penyuluhan oleh educator $45 \%$ responden memiliki pengetahuan tentang jajanan kariogenik pada kategori sedang. Dan setelah dilakukan penyuluhan dengan menggunakan metode peer edukasi, ada perubahan peningkatan pengetahuan responden menjadi $40 \%$ responden memiliki pengetahuan dengan kategori tinggi, dengan hasil uji t test diperoleh $\mathrm{p}<0,05$, hal ini bermakna ada perbedaan tingkat pengetahuan responden antara sebelum dan sesudah diberikan penyuluhan dengan metode peer edukasi.

Anak usia sekolah yang berada di Desa Kandang, sangat kurang terpapar dengan informasi kesehatan gigi dan mulut. Kegiatan UKGS di sekolah hanya 1 tahun sekali, kegiatan penyuluhan kesehatan juga sangat jarang dilakukan di Desa. Oleh karena itu, anak-anak hanya mendapat informasi menyikat gigi dari iklan di televisi, sementara terkait jajanan sehat, risiko mengkonsumsi jajanan tidak sehat seperti makanan yang bersifat kariogenik belum pernah di dapatkan. 
ABDI WIRALODRA

JURNAL PENGABDIAN KEPADA MASYARAKAT
ISSN 2656-5501 (Print)

ISSN 2714-8041 (Online)

Kegiatan pengabdian berupa penyuluhan kesehatan melalui metode peer edukasi, belum pernah mereka dapatkan, sehingga sangat terlihat educator dan siswa yang diajarkan oleh tim educator sangat antusias. Awalnya semua masih malu-malu, namun semakin banyak informasi yang didiskusikan dalam proses peer edukasi, terlihat sangat baik tentunya dapat dilihat dari hasil pre dan post test pada responden,

Sebagian besar responden masih mengingat informasi yang diberikan oleh temannya sendiri, sehingga dapat menjawab pertanyaan yang pernah diberikan sebelum dilakukan penyuluhan oleh teman sebaya. adanya diskusi pada siswa yang mendapat peer edukasi, di dukung oleh penggunaan media oleh siswa edukator, sehingga memudahkan siswa untuk mengingat dengan baik. Diskusi merupakan suatu proses pertukaran informasi, pendapat dan hal-hal yang bersifat pengalaman secara teratur dengan maksud untuk mendapatkan pengertian bersama yang lebih jelas, teliti tentang sesuatu atau untuk merampungkan kesimpulan atau pernyataan (Lotfi Mainbolagh et al., 2012).

Intervensi promosi kesehatan berupa pendidikan kesehatan pada anak usia sekolah dan keluarganya sangat penting diberikan,supaya mereka mempunyai pengetahuan tentang makanan sehat bergizi serta dampak yang timbul akibat mengkonsumsi jajanan yang salah melalui pendidikan kelompok sebaya. Lingkungan sosial sangat berpengaruh terhadap perkembangan anak usia sekolah, kemampuannya dalam interaksi antar teman sebaya (peer) memberi kesempatan besar untuk dapat berapresiasi, saling memahami, menerima perbedaan dan menekan perilaku egosentris serta membiasakan anak untuk berargumentasi terhadap suatu hal (Hockenberry, 2007)

Bentuk transaksi interpersonal terhadap teman sebaya adalah dalam bentuk perhatian emosional (empati), bantuan (jasa, informasi), dan pernyataan (umpan balik konstruktif, pengakuan). Hal ini di dukung oleh Frankle dan Owen (1993) pendidikan sebaya memberi banyak keuntungan terhadap anggotanya, seperti saling memberi dukungan, saling memotivasi dan saling menghargai antar sesama. Anak usia sekolah dalam bersosialisasi terhadap kelompok sebaya membuat aturanaturan yang harus di patuhi oleh anggotanya dan mereka belajar untuk saling 
menghargai pendapat, memperlihat kemampuannya, memelihara reputasi anggotanya, saling membantu dalam menyelesaikan masalah (Bomar, 2014).

Pengetahuan adalah suatu kondisi pemahaman seseorang setelah melakukan pengamatan terhadap suatu objek tertentu. Pengamatan menggunakan panca indra manusia, yaitu indra penglihatan, pendengaran, penciuman, rasa dan raba. Manusia dapat memperoleh pengetahuan lebih banyak melalui indra penglihatan dan pendengaran (Notoatmodjo, 2007).

Pemeliharaan kebersihan gigi yang kurang baik, dengan membiarkan sisasisa makanan menempel pada gigi yang disebut plak. Jika plak tidak dibersihkan akan menjadi tempat berkembang biaknya kuman. Hasil proses kimiawi antara plak, kuman dan air ludah akan menjadi asam. Asam ini dapat menimbulkan kerusakan pada email gigi yang dapat menyebabkan karies pada gigi. Upaya pemeliharaan kesehatan gigi seperti tehnik menyikat gigi yang baik dan benar, menggunakan alat atau sikat gigi yang lembut, merupakan hal penting yang perlu menajdi perhatian dari orang tua. Sehingga dapat memberikan fasilitas yang cukup untuk anak dapat dengan mudah membersihkan giginya. (Sakti, 2019)

Umumnya anak-anak memasuki usia sekolah mempunyai risiko karies yang tinggi, karena pada usia sekolah ini anak-anak biasanya suka jajan makanan dan minuman sesuai keinginannya. Pemilihan responden usia berusia 8-12 tahun. Anak-anak pada usia ini rentan terhadap pertumbuhan dan perkembangan karies gigi karena memiliki kebiasaan jajan makanan dan minuman baik di sekolah maupun di rumah (Sakti, 2019).

Anak usia sekolah di Desa Kandang, memiliki kebiasaan yang buruk dalam hal menyikat gigi, biasanya tindakan menyikat gigi hanya dilakukan pada saat mandi pagi saja, dan mandi sore jarang sekali menyikat gigi. Ditambah lagi dengan kebiasaan mengkonsumsi jajanan yang bersifat kariognik, yang banyak di sajikan di warung-warung dekat tempat tinggal, seperti donat coklat, kue serikaya, roti selai, dan lain-lain. Serta jajanan disekolah yang lebih dominan menjual jenis permen, coklat, biscuit, es cream, minuman bersoda dan minuman sotf dring lainnya.

Kebiasaan anak yang mengkonsumsi jajanan tidak sehat, terutama yang mengandung gula dan karbohidrat, dapat mengakibatkan terbentuknya plak, 


\section{ABDI WIRALODRA}

JURNAL PENGABDIAN KEPADA MASYARAKAT
ISSN 2656-5501 (Print)

ISSN 2714-8041 (Online)

didukung oleh kebiasaan anak yang menggosok gigi hanya pada waktu mandi, bukan setelah sarapan. Karies gigi dapat terjadi melalui proses patologis kerusakan gigi yang terjadi secara progresif disebabkan oleh kombinasi dari faktor langsung seperti diet, host, mikroflora dan waktu yang saling mempengaruhi satu sama lain. Diet merupakan asupan karbohidrat, host berupa kuantitas dan kualitas saliva, serta kualitas dari gigi, mikroorganisme yaitu mutans streptoccocus dan Laktobasilus sp, merupakan bakteri asidogenik berkoloni pada permukaan gigi. Waktu merupakan lamanya jangka waktu terpapar gigi oleh inorganik yang dihasilkan oleh bakteri dari plak gigi. PH Plak dan kematangan plak merupakan prediktor yang baik untuk terjadinya karies gigi (Sakti, 2019).

Peer edukasi yang dilakukan pada anak usia sekolah di Desa kendang, tentunya memiliki kontribusi, dalam transfer knowledge kepada teman sebayanya. Setiap infromasi yang diberikan akan lebih mudah diserap dan diingat. Kemudian rentang waktu pelaksanaan pre dan post test tidak terlalu jauh, sehingga mudah untuk mengingatnya (Lotfi Mainbolagh et al., 2012).

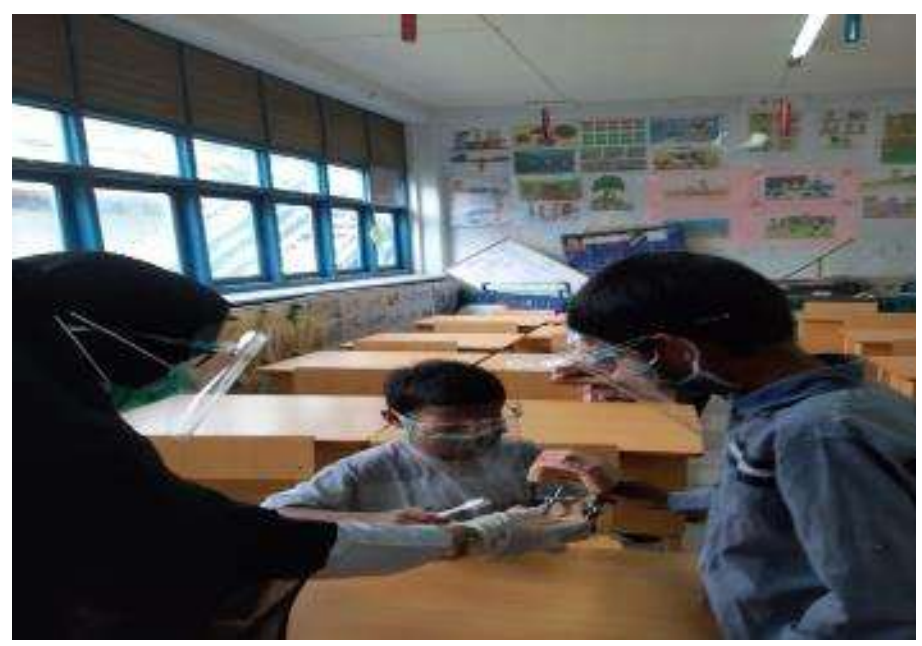

Gambar 3. Siswa yang menjadi educator sedang mengajarkan siswa yang lain, bagaimana cara menyikat gigi yang baik dan benar dengan menggunakan phantom gigi.

Gambar 3. Menunjukkan educator sedang membantu teman sebayanya untuk melakukan sikat gigi yang baik dan benar. Kegiatan dilakukan oleh educator dan teman sebaya dengan sangat menyenangkan, karena sebelumnya belum pernah melihat dan memegang phantom gigi dalam ukuran besar, dan terlihat sekali rasa ingin tahu anak-anak. 


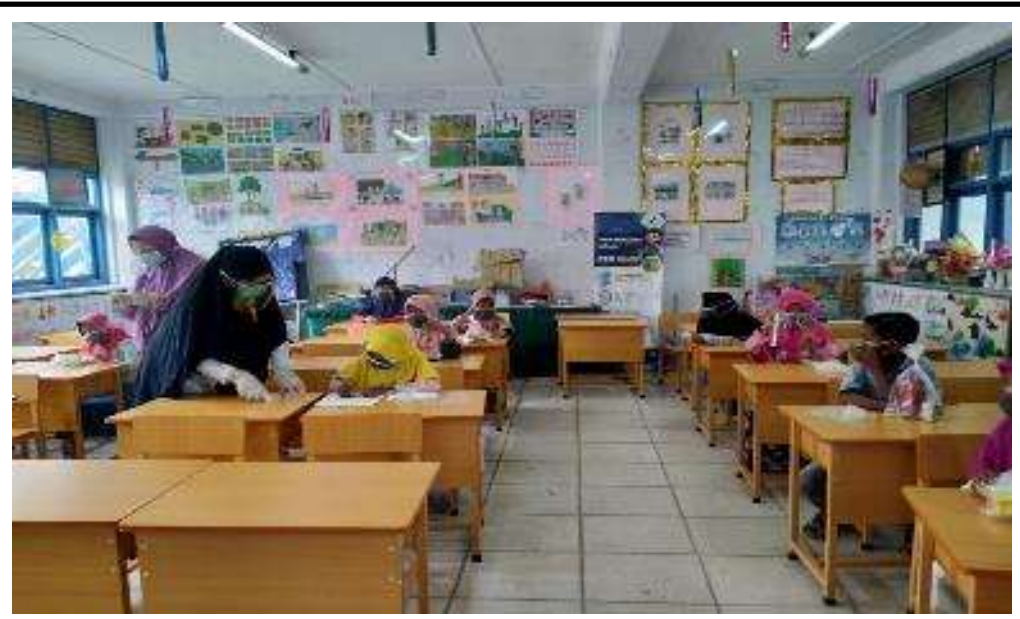

Gambar 4. Siswa educator sedang mengerjakan post test setelah diberikan penyuluhan dengan metode peer edukasi

Gambar 4. Menunjukkan kelompok belajar sedang menjawab pertanyaan post test, yang diberikan setelah educator memberikan materi pada kelompok belajar. Tim kegiatan pengabdian masyarakat terlihat membantu kelompok belajar, apa bila ada pertanyaan yang tidak dimengerti oleh anak.

Hasil kegiatan pengabdian masyarakat sesuai tabel 4, menunjukkan bahwa sebelum pre test $45 \%$ memiliki tindakan kurang baik, setelah dilakukan peer edukasi tindakan anak terhadap menyikat gigi meningkat menjadi 77,5\%. Hasil Uji Paired $\mathrm{T}$ test nilai $\mathrm{P}$ value adalah 0,001 . Hal ini bermakna ada perbedaan tindakan respoden setelah mendapatkan peer edukasi tentang jajanan kariogenik dalam hal pencegahan dengan menyikat gigi yang baik dan benar.

Menggosok gigi adalah membersihkan sisa makanan bakteri dan plak. Dalam mmebersihkan gigi harus memeperhatikan pelaksanaan waktu yang tepat dalam membersihkan gigi, penggunaan alat yang tepat untuk membersihakan dan cara yang tepat untuk membersihkan gigi. Pada usia anak sekolah (6-12) tahun sering disebut sebagai masa-masa laten yang rawan, karena pada massa itu lah gigi susu mulai tanggal satu persatu dan pemanen pertama mulai tumbuh. Keberadaan gigi yang beragam antara gigi susu dan gigi permanen, menandai anak sedang dalam masa gigi bercampur. Gigi yang baru muncul tentunya sangat rentan terhadap kerusakan gigi (Potter dan Perry, 2005)

Usia sekolah dasar merupakan saat yang paling tepat untuk melatih kemampuan gerak anak, termasuk diantaranya gerakan menggosok gigi. Serta kemampuan untuk memilih jenis makanan yang dikonsumsi, makanan kariogenik 
akan lebih cepat membuat gigi menjadi rusak dan lebih sulit untuk bersihkan dibanding dengan makanan yang berserat, seperti buah-buahan dan sayuran. umur seseorang dapat memperngaruhi pengetahuan, orang tua cenderung memiliki pengetahuan dan pengalaman yang lebih baik (Hurlock, 2007).

Kebiasaan yang tidak baik dalam menjaga kebersihan gigi dan mulut dapat berakibat pada munculnya berbagai penyakit sistemik seperti karies, gingivitis, radang, stomatitis, dan juga dapat berakibat pada kerusanakan jaringan periondontal gigi. Penyebab lainnya yang ditemukan bahwa mereka banyak mengkonsumsi makanan manis dirumah sekolah dan kurang sekali yang sadar bahwa pentingnya menyikat igigi sesudah makan dan sebelum tidur malam. Sebab makanan yang tersngkut digigi akan menjadai tempat bagi bakteri yang menjadi penyebab kerusakan gigi (Pratiwi, 2009)

Upaya pencegahan primer dalam bentuk promosi kesehatan untuk meningkatkan kesadaran individu, keluarga, kelompok dan masyarakat terutama anak usia sekolah berupa kesalahan dalam menentukan jajanan yang dapat mengakibatkan berbagai ancaman kesehatan. Dengan harapan kegiatan peer edukasi dapat menjadi program penting bagi setiap instansi pendidikan terutama pada siswa sekolah dasar untuk meningkatkan derajat kesehatan siswanya. Sebagai langkah awal untuk menciptakan generasi yang sehat dan cerdas.

Pada saat educator memberikan latihan menyikat gigi, semua kelompok terlihat antusias untuk mencoba melakukan menyikat gigi pada media phantom. Namun, karena mengingat waktu, hanya 3 orang anak saja yang di undi secara acak untuk mempraktekkan cara menyikat gigi dengan phantom. Keterampilan adalah kemampuan seseorang yang diperlukan untuk dapat melaksanakan beberapa tugas sebagai dampak dari mengikuti pelatihan dan pengalaman yang didapat. Keterampilan ini dapat berkembang menjadi interpersonal skill, yang merupakan kemampuan seseorang secara efektif untuk berinteraksi dengan orang lain maupun rekan, sehingga ada proses pembelajaran di sana (Pontonuwu, 2013).

\section{Kesimpulan dan saran}

1. Adanya perubahan pengetahuan dan tindakan educator sebelum dan sesudah diberikan materi tentang peer edukasi tentang jajanan kariogenik 
2. Adanya peningkatan pengetahuan anak usia sekolah setelah diberikan penyuluhan tentang jajanan kariogenik oleh teman sebaya (educator) melalui metode peer edukasi $(\mathrm{p}<0,05)$.

3. Adanya peningkatan tindakan anak usia sekolah setelah diberikan penyuluhan tentang jajanan kariogenik oleh teman sebaya (educator) melalui metode peer edukasi $(\mathrm{p}<0,05)$.

Berdasarkan hasil kegiatan yang dilakukan di Desa kendang, maka dapat disarankan kepada pihak puskesmas agar dapat membuat upaya/program puskesmas untuk anak-anak usia sekolah di Desa kendang, untuk mengembangkan proses belajar tentang materi kesehatan gigi melalui metode peer edukasi. Kemudian agar dapat meningkatkan kegiatan program UKGS di sekolah yang ada di Desa Kandang. Dengan harapan, adanya perubahan perilaku dari anak usia sekolah ke arah yang lebih baik, terutama tentang cara pemeliharaan kebersihan gigi dan mulut melalui pencegahan karies dengan mengetahui tentang jajanan kariogenik. Serta melibatkan orang tua atau keluarga dalam melakukan upaya pemeliharaan kesehatan gigi dan mulut anak.

\section{Daftar Pustaka}

Afrilina, G., (2006), 75 Masalah Gigi Anak Dan Solusinya, Gramedia; Jakarta Anggriana, D., (2004), Faktor Pendorong Motivasi Orang Tua Merawat Gigi Anak , Skripsi, Fakultas Kedokteran Gigi Universitas Airlangga, Surabaya.

Ariani, (2011), Faktor-faktor yang Berhubungan dengan Pemilihan Makanan Jajanan Pada Anak SD. Artikel Penelitian. Undip, Semarang

Bomar. Pj., (2014), Promoting Health in Family : Applying Family Research and Theory to Nursing Practise, Philadephia : Sounders

BPOM. (2013). Pedoman Pangan Jajanan Anak Sekolah untuk Pencapaian Gizi Seimbang Bagi Orang Tua, Guru dan Pengelola Kantin. Direktorat Standardisasi Produk Pangan Deputi Bidang Pengawasan Keamanan Pangan Dan Bahan Berbahaya Badan Pengawas Obat Dan Makanan Republik Indonesia.

Chemiawan E, Riyanti E, Tjahyaningrum SN.(2004), Prevalensi nurshing mouth caries pada anak usia 15-60 bulan berdasarkan frekuensi penyikatan gigi di posyandu desa Cileunyi Wetan Kecamatan Cileunyi Kabupaten Bandung.

Dwi, N. S., (2010), Hubungan Pendidikan, Pengetahuan, Perilku Ibu Terhadap Status Karies Balitamya Dikecamatan Medan Selayang, Skripsi, Fakultas Kedokteran Gigi Universitas Sumatera Utara, Medan

De Vreede, C., Warner, A., \& Pitter, R. (2014). Facilitating youth to take 
sustainability actions: The potential of peer education. Journal of

Environmental Education. https://doi.org/10.1080/00958964.2013.805710

Fatimatuzzahro, N., Prasetya, R. C., \& Amilia, W. (2016). Gambaran Perilaku

Kesehatan Gigi Anak Sekolah Dasar di Desa Bangalsari Kabupaten

Bantaeng. Jurnal IKESMA.

Hockenberry, et al., (2007), Nursing Care of Infant and Children, The Mosby : St

Louis

Liana, I. (2018). Pengaruh Pendidikan Sebaya Terhadap Tindakan Pemilihan Jajanan Sehat Pada Siswa SDN 62 Lueng Bata Banda Aceh Tahun 2016. Averrous: Jurnal Kedokteran Dan Kesehatan Malikussaleh. https://doi.org/10.29103/averrous.v2i2.422

Lotfi Mainbolagh, B., Rakhshani, F., Zareban, I., Alizadeh Sivaki, H., \& Parvizi, Z. (2012). The effect of peer education based on health belief model on nutrition behaviors in primary school boys. Journal of Research and Health.

Machfoedz, I., (2008), Menjaga Kesehatan Gigi dan Mulut Anak -anak dan Ibu Hamil, Fitramaya, Yogyakarta, hal: 108.

Natamiharja, L. Dwi, S. N., (2010), Hubungan Pendidikan, Pengetahuan, dan Perilaku Ibu Terhadap Status Karies Gigi Balitanya, Jurnal, Departemen Kesehatan Gigi Masyarakat Fakultas Kedokteran Gigi Sumatera Utara, Medan.

Nunik Kusumawardhani, SKM, Ms.Ph. (2007). Pengembangan Promosi kesehatan Berbasis Sekolah Untuk Pengendalian Perilaku Beresiko pada Pelajar SLTP di Kota Depok. http://www.bmf.litbang.depkes.go.id

Messakh, S. T., Purnawati, S. S., \& Panuntun, B. (2019). Gambaran Perilaku Hidup Bersih Dan Sehat Siswa Sekolah Dasar Negeri Di Kecamatan Bancak. Jurnal Ilmu Keperawatan Dan Kebidanan. https://doi.org/10.26751/jikk.v10i1.477

Notoatmodjo, S. (2007). Promosi Kesehatan Dan Ilmu Perilaku. Rineka Cipta.

Nurbiyati, T., \& Wibowo, A. H. (2014). Pentingnya Memilih Jajanan Sehat Demi

Kesehatan Anak. Jurnal Inovasi Dan Kewirausahaan.

Pontonuwu, J, Manati, N.W, \& Wicaksono, D.A, (2013), Gambaran Status Anak

Sekolah Dasar di Kelurahan Kinilow 1 Kecamatan Tomohon Utara Mando.

Http://ejurnal.unisial.ac.id/index.Php/egigi/artikel/view/3145

Rahmayanti, S \& Purnakarya, I (2013), 'Peran Makanan Terhadap Kejadian

Karies Gigi’.Jumal Kesehatan Masyarakat, Vol. 7, No. 2.

Santoso, S dan Ranti, A.L. (2009). Kesehatan dan Gizi. P.T Rineka Cipta dan P.T Bina Adiaksara: Jakarta. Hal 17-28

Reitz, S. M., \& Graham, K. (2018). Health promotion theories. In Willard and Spackmans Occupational Therapy, 13th Edition. https://doi.org/10.1007/9781-4020-5614-7_1458

Sakti, E. S. (2019). Faktor Risiko Kesehatan Gigi dan Mulut. In Pusat Data dan Informasi Kementerian Kesehatan RI. 